\title{
Women in Politics: A Case Study of Iran
}

\author{
Seyedeh Nosrat Shojaei \\ Politics \& Government, Universiti Putra Malaysia (UPM) \\ 29-20, Pangsapuri Vista Impiana, Taman Bukit Serdang, Seksyen 10 \\ 43300 Seri Kembangan, Selangor, Malaysia \\ Tel: 60-17-243-5107_E-mail: nosrat2007@yahoo.com \\ Dr. Ku Hasnita Ku Samsu (corresponding author) \\ Department of Government \& Civilization Studies \\ Universiti Putra Malaysia (UPM) \\ Department of Government \& Civilization Studies \\ Faculty of Human Ecology, \\ Universiti Putra Malaysia, 43400 UPM Serdang, Selangor, Malaysia \\ Tel: 60-19-219-7677Ｅ-mail: hasnita@putra.upm.edu.my \\ Hossien Asayeseh \\ Politics \& Government, Universiti Putra Malaysia (UPM) \\ 29-20, Pangsapuri Vista Impiana, Taman Bukit Serdang, Seksyen 10 \\ 43300 Seri Kembangan, Selangor, Malaysia \\ Tel: 60-17-249-5834Ｅ-mail: h.asayesh@yahoo.com
}

\begin{abstract}
Although the involvement of women in the political process as half of the world population is necessary to strengthen democracy, their place is inadequately established in active political life. At every socio-political level around the world, women found themselves as being under-represented in political decision-making. Iranian women are no exception. This paper examines women's political participation in three different historical periods in Iran, namely the Qajar Dynasty, Pahlavi Dynasty, and the period of the Islamic Republic, to show the extent of women's involvement in Iranian' politicos. This paper also examines the hindering and facilitating factors that affect the political participation of women in Iran.
\end{abstract}

Keywords: Political participation, Women, Iran, Qajar Dynasty, Pahlavi Dynasty, Islamic Republic

\section{Introduction}

Political participation is understood as a prerequisite to political development (Huntington, 1965). Hence, by improving women's political participation may help to advance the political development and to improve the quality of women's and children's lives, considering the fact that they constitute over a half of the world's population.

This article considers the importance of women in the political process and the social development through three different historical periods in Iran, namely Qajar Dynasty (Note 1), Pahlavi Dynasty (Note 2) and the period of the Islamic Republic. Additionally, a comparison between the women's political participation in Iran with other countries, as well as the analysis of the most crucial facilitating and hindering factors affecting the Iranian women's political activists are the two other issues addressed in this paper.

\subsection{Women's political participation in Qajar Dynasty}

Until 1906, the system of Iranian government in the period of Qajar was of a monarchic type, and people had little role in determining the policy. In this period, the position of women in terms of their presence in political and social spheres was negligible, as compared to men.

Indeed, during the Qajar period, the social structure of Iran was rather traditional, and it made no provision for the formal education of women, except for the reading of religious texts such as the Quran. Meanwhile, the old-fashioned primary schools were located in mosques or special houses known as "Maktabkhaneh". However 
some religious-minded families retained private tutors to give instruction to their daughters in their households. These girls learned to read the Quran. The traditional Iranian society considered giving birth to children and doing housework the primary duties of women and confined men and women to separate parts of the house (Enayat, 2001).

Women were not allowed to go out of their homes. During this period, there was also a gender separation in homes and streets, and this continued until the Pahlavi period, especially among those in the lower classes of society. Sansarian (2005) stated that in the period of Pahlavi, "women who wanted to go to the other side of the street they will be allowed from the guard and the men...and women did not have the right to sit together in a carriage even if they were mothers and son or brother and sister" (p.30).

In addition, child marriage and forced marriage of girls were also very common during this period. Also, divorce was very easy for men and polygamy was permitted for men. In fact, women's attitude to their status was to accept their destiny. In other words, patriarchal norms helped to structure gender relations where women were apparently subordinate to men and had no share in their families or social decision-making.

In the political system of Iran, the Shah enjoyed absolute power and took all decisions himself without consulting others (Enayat, 2001). This paternal absolutism affected all segments of the Iranian society and brought about a male-dominated culture. This culture is similar to the one remarked by Javaheri and Ghazati (2007) and Shaditalab (2002). Their studies show that in the managerial sections and resolution, particularly the political section, women mostly encountered cultural and traditional obstacles which resulted from the values and beliefs that rooted in the cultural domains of the Iranian society. These affected the men and woman's ways of thinking, which consequently led to the seclusion of women in politics.

Women's position in the Qajar's era is of particular significance since it coincides with the emerging women's social and political movements in the West. In fact, two movements on the part of people took place in Iran in Qajar's era, and this was in response to the demands of the dictators of the time, in which the fundamental role of women could not be denied (Mohammadi, 2009). These movements are described in further details in the following parts.

\subsubsection{Tobacco Protest}

One of the events in which Iranian women participated was the Boycott of Tobacco. The Tobacco Protest was a Shi'a cleric-led movement in Iran against a tobacco concession granted by the Shah to the Western imperial power of the Great Britain in 1890. According to Shamim (2008), this concession granted Great Britain a full monopoly over the production, sale, and export of tobacco in Iran for fifty years. The protest climaxed in a widely-obeyed fatwa against tobacco use issued by the Grand Āyat-Allāh Mirza Shirazi (Note 3) in December 1891. It is important to note that women participated along with men from the beginning to the end of this movement. For example, women (including those at the Court who had never failed to obey the king) played an active role in this event and broke all the hookahs, following their religious leader, Mirza Shirazi, and resisting against the direct orders and the absolute power of Nasir al-Din Shah (Note 4).

According to Delrish (1996), the role of Iranian women in the Tobacco movement was significant, but traditional views and patriarchy culture did not allow women to use of this movement to improve their situation in society.

\subsubsection{Constitutional Revolution (Enghelabe Mashroute)}

Women also played an undeniable role in another event, i.e. the Constitutional Revolution, which occurred in the early $20^{\text {th }}$ century in Iran. This revolution can be regarded as a turning point in the history of Iran.

Constitutional Revolution was the result of the effort of many Iranian people. Women also participated actively in this important political and social movement. In fact, women's participation in this revolution can be considered as effective and important in two ways. First, women were present in some of its events in the shadows. For instance, bodies of 20 women who disguised in men's clothing and took part in the fights were found among the revolutionary martyrs in the area of Azerbaijan when the Iranian National Commander, Sattar Khan, rose against the tyranny of Qajar Kings and the influence of foreign governments (Shamim, 2008). In addition, after the gathering during the protest in front of the British Embassy, the objecting women occasional gathered in the streets of Tehran. In particular, the women explicitly denounced the brutality and encouraged the rioters to resist against the government after the murder of the first Constitutional warrior, Seyed Abdol Hamid.

It is also worth highlighting the effective role of women in the Constitutional Revolution when a group of women formed assemblies to carry out socio-political activities. For instance, they were divided in several groups to protect of clergymen who came to mosques to attend lectures on the advantages of constitutional government and criticism of the tyranny system. Therefore, the social activities of women were found to increase 
during the Constitutional Revolution. Among other, they created private associations and hidden organizations, participated in the protests, and also struggled for the victory of the armed and non-violence Constitution (khodadad, 2008).

In addition to their active roles in the movement, the Iranian women proclaimed their social rights against issues like polygamy and men's monopolized right of divorce during the Constitutional Revolution. Even some male intellectuals from among journalists and poets supported women's rights.

After the Mashroteh Movement in 1906, the urban middle- and upper-class women were allowed limited social and political participations. The women's participation in politic has also been witnessed since then, and they regularly publish a journal called "Nesvan" (Women). The early $20^{\text {th }}$ century also witnessed the growth of institutions for girls' education. From 1920's onwards, formal education has been regarded as essential for women. However, many parents did not allow their daughters to get educated because of their conservative culture. However, the educational system was designed in such as way that it provided opportunity only to the rich and the urban few (Keddie \& Richard, 1981).

From 1907 to 1911, women's activities were more serious in the Qajar period. They formed several organizations, such as Women's Freedom Forum, Women Unions and Revolutionary Women Forum (Afarai, 1998). These organizations criticized the dominant patriarchal culture, the lack of proper education for girls and women, and the denial of the right to vote for women.

Another achievement of the Constitutional Revolution for women was that they could express point of views through constitutional newspapers. In fact, from 1908 to the start of the first Pahlavi, seven women's magazines and newspapers with following names, Danesh (knowledge), Shokoofeh (Blossom), Zaban Zanan (Women's Language), Nameh Banovan (Women's Letter), Jahane Zanan (the World of Women), and Jameiat Nosvan Vatankhah Iran (The Iranian Patriot Female Population), were gradually released.

Afarai (1998) is apparently aware of the fact that the beginning of the Iranian women's political movement had occurred during the early $20^{\text {th }}$ century when he asserts, "in those days, women activist who commonly came from the upper class started to establish women's assemblies, unisex schools, health centres and several other institutions for girls and women" (p. 9). Nonetheless, women were still denied the right to vote despite the effective role they played in the Constitutional Revolution.

The Constitutional Law and the election rights it entailed deprived women of political participation and specified it to men (Maknun, 2000). As a result, a number of women objecting to the deprivation of women from political movements wrote a letter to the Parliament in order to complain against the First Parliament's inadequacies, demanding it to involve women in the political affairs of the country to improve its conditions.

\subsection{Women's Political Participation during the Pahlavi Dynasty}

\subsubsection{The First Pahlavi Era}

The status of women in Iran drastically changed when Reza Khan came to power in 1925 and "emphasized the importance of women within the state because they made up half of the population" (Chaido, 2006, p. 1).

Reza Khan Pahlavi had most often been characterized as an authoritarian ruler, whose vision of modernizing Iran was directly influenced by Kemal Ataturk and his plan of modernizing Turkey. Reza Shah Pahlavi was detested by many because of the things he did in the name of modernization. For example, he abolished the veil in 1936 and sent his daughters and wife to public places without their veils. They also started wearing Western dresses. Removing the veil and wearing Western dresses were also the symbolic of the onset of modernization.

The Shah also made great contributions in the area of education. Early in his administration, the Shah had realized that "without a radical change in her (woman's) situation, any progress would be condemned to remain incomplete" (Haas, 1946, p. 160). In 1935, i.e. the year after Tehran University was founded, women were given permission to enrol into it. The circumstances under which the girls attended the university were far from ideal, but their presence was nevertheless noteworthy (Chaido, 2006).

Apparently, things were slowly starting to change for the better for women in Iran. More freedom of women in public places helped in shifting women's sphere of operation from domestic to public premises. In fact, women began to enjoy more freedom and opportunity than what was available to them earlier. By the 1950's, the western culture had almost overtaken the high-class urban society. "Westernized women were employed in production industries, mainly in the teaching and nursing professions, which helped in reinforcing the norms of the traditional division of labour among genders" (Keddie \& Richard, 1981, p. 57). According to Esfandiari (1977), "this work gave middle-class women the experience in running organizations, brought working-class women 
into contact with the new ideas, and helped expand the constituency for women's causes" (P.25). Even with the reforms undertaken by Reza Shah, however, "no substantial social or political reform or emancipation was envisaged" (Beck \& Nashat, 2004, p. 95). During Reza Shah's monarchy, women were not allowed to participate in elections since Article 15 of the Constitutional Law deprived women and those who had not reached the right age from voting. In fact, women never found any opportunity to participate in any political activities or elections during his time as the king. This rule was valid even in the time of Mohammad-Reza Shah, who was the Second Pahlavi, until 1961 (Mohammadi, 2009).

In general, women in Reza Shah's era, as in the Constitutional period, were denied political rights, and could not claim their rights based on the principles of democracy in the strangulation political atmosphere (Chaido, 2006). The reason was the lack of independent political and non-political organization in a civil society (Chaido, 2006). In the absence of civil society, they could not obtain their required experiences for gaining their right. In this vacuum, women connected to the Pahlavi Court established communities, organizations and associations and wanted to share in social activities show their talents, but this could not establish areas for growth and progress in the women's movement (Chaido, 2006). Even Iranian female reformists had to face two major barriers, namely the lack of civil society and the Iranian men's disagreement which was originated from the belief and prevailing tradition in the society. Therefore, it should be pointed noted that "unveiling at the time of Reza Shah and political repression that dominated on society caused all women to be unable to participate in the whole social activities" (Kar, 1977, p. 23).

\subsubsection{The Second Pahlavi Era}

Reza Shah Pahlavi abdicated in favour of his son, Mohammed Reza Shah who became the king of Iran from 1941 to 1979. In the first year of his reign, there were no noticeable changes as far as women's rights were concerned. However, one of the most important years for Iranian women under his ruling was in 1963, when they gained the right to vote. Obviously, it is not something that was easy for them to accomplish, and it had taken many years, many demonstrations and disapprovals from the clerical community. However, Mohammed Reza Shah finally decided to permit women to vote and to be elected to government office beginning 1963 (Chaido, 2006).

In general, the women's place in the Iranian society improved rapidly after 1963 in all sectors. For example, one could find women working in the civil area, appointed as ministers in the government, and members of the police force. Meanwhile, others worked in the private sector as factory workers, clerical assistants, and secretaries. Women's participation in secondary and higher education increased and so did the opportunities for them to study abroad. As a result of their education and search for improvement, women started migrating from their villages to small towns and eventually to larger cities. They tasted freedom and a life outside the house in which they had traditionally been denied off.

Another important year for women was 1967 because the enactment of the Family Protection Law (FPL) further allotted them more freedoms in matters of divorce, polygamy, custody of children, travelling, and studying abroad. At the same time, the official marital age rose to eighteen and women were finally allowed to become judges and lawyers, as well as pleaded their cases in front of courts. Therefore, reforms in the sphere of marriage, employment and education introduced during the Shah's regime were aimed at ameliorating the status of women (Enayat, 2001). The hasty introduction of the social reforms wrapped within the project westernization led to increasing social differentiation and rampant corruption in the Iranian society and created a sense of social and political instability. Moore (1988) describes this in the following manner, "it encouraged western values and lifestyles and inculcated among the masses a sense of loss of national and cultural identity" (p. 34).

However, these reforms helped only a few women from the upper class citizens to achieve their social and political positions, but they did not lead to any large scale participation of women in decision-making positions.

Maknun (2000) states that "women's political activities during the monarchy of the second Pahlavi were not spontaneous or independent and could be identified as immature, dependent on the government, unbalanced and non-localized" (p. 189). In fact, the presence of women in politics in this period should be considered not an actual political participation, but a deliberate propaganda. Thus, the political presence of women in a mass did not occur during the Pahlavi Dynasty; on the contrary, their widespread participation beside men came about during the process of the Islamic Revolution in the form of their protests against the Pahlavi Monarchy.

\subsection{Women's Political Participation during the Islamic Republic of Iran}

Due to the importance of women's role in the Islamic Revolution and the increasing trend of women's political participation in the period after the 8-year Iran-Iraq War, the two crucial periods of the process of women's 
political participation in the contemporary history of Iran are discussed therefore discussed in the subsequent section.

\subsubsection{The Islamic Revolution}

In April 1979, following a revolution, the people of Iran decided to change the country's political system, i.e. from a monarchy to an Islamic Republic. Iranian women played a critical role in the revolution, marching abreast with men, supporting their husbands, and encouraging them to fight. One of the most vivid images of the Iranian revolution is a slew of women in black chadors marching in city squares and protesting against the Shah (Topuzoglu, 2004) .

Some of these women, who had participated in the political activities together with men, were arrested and, as political prisoners, they suffered many painful tortures which resulted in their martyrdom. As people continued the fight, resisting against the government, Iran entered a new era of its history and the people's revolution commenced.

Despite their limited political knowledge, the women in this period participated in the process of revolution and the genesis of revolutionary activities in a variety of ways, some of which include:

- distributing news and announcements

- $\quad$ organizing charitable activities and satisfying social needs like helping the wounded and providing shelter for the activists

- participating in demonstrations and street rallies

- helping to make obstacles in the way of police forces

- $\quad$ taking part in hidden political activities

- $\quad$ participating in armed fights, making and using weapons

- $\quad$ taking part in political meetings and speeches

In fact, the role of women in the Islamic revolution is of particular importance because if they had not participated in the revolutionary activities, they could have played the role of prevention forces against men, including husbands, children and brothers. Therefore, it goes without saying that in this way the probability of a revolution would have decreased.

As a matter of fact, it was because of this active, extensive and effective participation of the Iranian women that Imam Khomeini, as the leader of the Islamic Revolution, in appreciation of their participations, frequently pointed out the roles and influence of women in the victory of the movement. The significance that women's social and political participation had for Imam Khomeini, as a religious scholar, and the way in which he interpreted the status and roles of women, in comparison to the beliefs of other great Islamic thinkers, is incomparable and at times unique. Below there are some important sentences used by Imam Khomeini to highlight the women's positions in the formation process of the Islamic Revolution:

Shah's prisons are filled with brave women. Our women have come to fight in the street rallies holding their children in their arms, undaunted by the tanks, canons and machine guns. The political meetings that women hold in various cities are not negligible. They have played an invaluable role in our fights (Khomeini, 1998, p. 120).

Which honour is higher than that of the women's manifestation of resistance while they were first in line against Shah's monarchic regime, and after its annihilation, against the world super powers and their dependants, a resistance and valour that has not been indicated by men throughout history (Khomeini, 2005, p. 194).

You, brave women, were and are pioneers in this victory [Islamic Revolution]. You encouraged the men. We are all indebted to your bravery (Khomeini, 1999, p. 153).

Perhaps it is because of these statements on the significance of women's participation in politics and society that even though today "Khomeini is criticized heavily, even by those in the Middle East for putting many restrictions on women and making sure everyone abided by the gender norms, within the context of the Revolution, he was a feminist in his own religious way" (V. Topuzoglu, 2004, p. 93).

\subsection{2 after the Islamic Revolution}

The victory of the Islamic Revolution and the revival of the real positions and dignity of women marked the beginning of the Iranian women's participation in political, social, economic and cultural areas, particularly actualized in the statement of the founder of this revolution, "women must contribute to the fundamental affairs 
of the country" (Khomeini, 1999, p. 153). In other words, it should be acknowledged that the Islamic Revolution is a historical landmark of women's active participation in various areas. In fact, the political participation of women after the Islamic Republic could be divided into three groups; (a) mobilized political participation, (b) traditional political participation, and (c) modern political participation.

To offer an example for the Iranian women's mobilized participation, their demonstrations and improvised marches during the Revolution can be mentioned. As for their traditional political participation, Iranian women's support can be mentioned back in the cities and villages, particularly during the imposed war of Iraq against Iran. They prepared food and clothing for the Army and at times, provided emotional and financial support. Finally, examples of the women's modern political participation in Iran include their mass level participation in periodic elections, associations and Non-Government Organizations, as well as the elite level participation in the parliament besides executive and judiciary positions.

The end of the imposed war of Iraq against Iran in 1988 created favourable opportunities for the increased participation of women at different levels of society. During the second decade of the Islamic Revolution and the period of Reconstruction from 1989 until 1997, a new approach evolved regarding women's issues. The establishment of the new institutions such as the Women's Bureau, affiliated to the Office of the President, was a stepping stone in the assessment and implementation of plans on women's issues, and it was during the official course of this Bureau that the measures taken laid the foundation for future actions (Shojaei, 2005).

The political participation of women was highlighted during Khatami's presidency. 76 percent of Iranian women voted for Mohammad Khatami. According to Mosaffa (2000, p. 5), Khatami "was the only candidate that offered the special plan for improvement of women's conditions". As indicated, this presidential election was extraordinary and, in fact, "challenged all the theories in women's political participation that refer to women as conservative" (Mosaffa, 2000, p. 5).

After President Khatami took office in June 1997, the reform was implemented in all areas, with particular emphasis being placed on strengthening women's participation in society, which brought about an institutional change in approaching women's issues.

In this period, the Women's Bureau in the Presidential Office was transformed to the Centre for Women's Participation (CWP), which played an extremely effective role in integrating gender perspectives in national policy-making. Alongside the activities of the CWP, Women's Committee in the provinces have become active in handling women's issues within the infrastructure of the government's decentralization policies (Shojaei, 2005).

Furthermore, the appointment of women to top administration and decision-making post increased their political participation during Khatami's presidency. Some examples of this trend include women's role of Vice president (Head of Environment Organization and a member of the cabinet), presidential advisor, head of the centre for women's participation and the member of cabinet, political advisor to the president, deputy minister in the Ministry of Culture and Islamic Guidance, the Ministry of Health, University chancellor and director general in different parts of the government.

From the above, it can be inferred that the Islamic Revolution was indeed a turning point in the Iranian women's history particularly, due to the quantitative and qualitative presence of women in different areas. In the Constitutional Law of the Islamic Republic of Iran, which was developed as the most important national evidence after the Revolution and based on the Islamic views and ideologies, some of its Acts evidently emphasized the protection of women's social and political rights. For example, Act number 20 of the Constitutional Law supports all individuals, man or woman, equally and emphasizes that all members of society, in relation to the principles of Islam, are of equal humanitarian, political, economic and cultural rights. It must, however, be declared in spite of all of the attempts made to protect women's rights, and this great human force still is faced with various obstacles and challenges. Studies have shown that women have not been paid adequate attention as a fundamental force in the development and progress of the country, and their participation in different directions, such as the presence in major decisions of society, their role is insignificant and marginal.

Of course, taking women's condition after the victory of the Islamic Revolution in various areas of power and decision-making positions, it is undeniable that women's negligible presence in the afore-mentioned areas has not been much different from their condition all over the world. According to the figures presented by the Inter-parliamentarian Union (IPU) in 2010, in order for women and men to actually reach equal social and political rights, a lot still needs to be done because in any of the countries of the world, women have not achieved even half of the seats in their parliaments. Only in some countries like Rwanda, Sweden, South Africa, 
Cuba, Iceland, Netherlands, Finland, and Norway, women have occupied more than $40 \%$ of the parliament seats (IPU, 2010).

According to the same source, Iran is ranked at $131^{\text {st }}$ place after the Kumar Islands in terms of the number of women in the parliament. Among the neighbours of Iran, countries that precede it in this ranking include Iraq $\left(36^{\text {th }}\right)$, Turkey $\left(107^{\text {th }}\right)$, Armenia $\left(106^{\text {th }}\right)$, Azerbaijan $\left(92^{\text {nd }}\right)$, Turkmenistan $\left(72^{\text {nd }}\right)$, Afghanistan $\left(29^{\text {th }}\right)$, Pakistan and United Arab Emirates $\left(47^{\text {th }}\right)$, while the countries are ranked behind Iran are Bahrain $\left(133^{\text {rd }}\right)$, Qatar, Oman and Saudi Arabia, all of which are the last, i.e. at $137^{\text {th }}$. Furthermore, according to the official site of the IPU organization, women hold only 11.2 percent of the whole 262 managerial positions in the executive and decision-making centres all over the world. However, if the political and social participation of Iranian women were to be compared with that of the other countries in the area, particularly the Islamic countries, and the results would not be heartening.

Meanwhile, the presence of several female ministers in the governments of most Islamic countries, such as Tunisia, Bahrain, United Arab Emirates, Oman, Afghanistan, Pakistan, Kuwait, Qatar, Yemen, Iraq and Malaysia, the employment of women as ambassadors by countries like Egypt, Tunisia and Afghanistan, in addition to the enforcement of party quotas in some Islamic countries such as Iraq, Afghanistan, Turkey, Pakistan, Egypt, and Yemen, have caused women to actualize their capabilities in the political and social aspects. Although women's condition in the society has changed and most of the official obstacles limiting or preventing women's activities have been removed after the Revolution in Iran, women's share in various aspects such as making and creating decisions, ratifying and executing rules in diplomatic areas has been neglected (Woman Studies and Research Center of Tehran University, 2002).

In addition, politically empowered presence rate of women in political administration and managerial positions is lower in the developing world including East Asia, Latin America and Sub-Saharan Africa compared with developed countries (Jaquette, 1997). Studies indicate that the average Parliament number of seats held by women in national legislative body is less than 10 percent (Khalili, 2007; Sook Kim, 2006). A glance at the statistics of the eight terms of the Parliament in Iran illustrates women's lower level of political participation in comparison with other countries. As indicated in Table 1, the Iranian females' participation rate during the last 8 Parliaments did not exceed 5.6 percent (Statistics Center of Iran, 2009).

Moreover, research has also revealed that Iranian women have a lower status than men in managerial positions. For example, from a total number of 17,563 governmental management positions, women occupy only two percent, while the number of male managers in Iran is thirty times more than that of the females (Davani, 2005; Khalili, 2007; Naji-Raad, 2003).

Worst still, the national plan surveying the women's political participation, proposed by the Women's Participation Affairs Centre during the presidency of Mohammad Khatami in 28 provincial capitals in Iran, indicated that Iranian women were at the lowest possible stage with only half of them were willing to share in especial political activities, in which the individuals in addition to their participations in elections, as the most common and public form of political activity, took part in other political activities. Meanwhile, memberships in political parties, organizations, groups and forums, collecting votes for candidates, applying for political positions, financial support of election candidates, and advertising for their favourite candidates in elections, lectures, writing papers, and participation in demonstrations, political gatherings and strikes are some of the indicators of especial political activities.

Besides the facts mentioned above, another proof of women's disappointing condition should be sought in managerial and vocational divisions. To offer an example, the percentage of working women in comparison with working men is 9.4 percent and the share of working women in major managerial positions is only 4.9 percent. Furthermore, the number of male managers is 30 times more than that of the female managers (Davani, 2005; Naji-Raad, 2003).

Therefore, based on the statistics which indicates the unsatisfactory status of women in various aspects only partially, what should be pointed out is that women's negligible participations in various social and political divisions can have disastrous consequences, deprive them from important rights and responsibilities as citizens, discard their viewpoints in making decisions and passing and executing rules as half the population of members of the society, deprive them of their rights in national budgets and resources, and most importantly, render the society deprived of their skills, knowledge and viewpoints (Molaverdi, 2005). That is why the experts in the area have stated that it is impossible to call a society developed unless all its members contribute, while social and cultural self-developments take place in it completely, and the demands and needs of women as half of the body of the society are met. 


\subsection{Hindering Factors}

Women's political and social participations in different countries all over the world have encountered obstacles in psychological, character, social, economic and political dimensions and the cultural factors seem to have played the most significant role in reducing the presence of women in the society, particularly in the managerial levels. Iran is no exception to the insignificant role women are required to play in the social and political activities.

Due to their vastness, cultural factors can take different forms. Variables like women's own ideology, their families' and social viewpoints, religious norms, and the common social customs can all be assumed as aspects of cultural factors. Hence, for the social and political participation of women to increase, there is a need for a comprehensive cultural planning that can elevate the level of public understanding in terms of the significance of women's social and political participations and trigger women's better realization of their own values and capabilities which can increase their social and political participations. Sociologists and researchers in the area of women's issues attribute the reasons behind the negligible participation of women in social and political activities to gender stereotypes and beliefs, owing to the prevalence of patriarchy beliefs in the society. In fact, such a patriarchy culture has resulted in dividing the responsibilities into housework and social work and leaving the house responsibilities to women, depriving them of the opportunity to have an equal share with men. Of course, such a division of responsibilities is not specific to Iran alone as there has been a division between the public and private areas in the West. Thus, "limiting women in the house and assuming their thoughts, ideas and actions to be unimportant will oppress their creativity and unlimited power within them, lowering their self-esteem and efficiency" (Shaditalab, 2002, p. 6).

Additionally, in Iran as well as in many other third world countries, women are not considered efficient and effective in most occupations. This prejudice roots from the opinion that a woman already plays the roles of a wife and mother, and when the responsibility of an occupation outside home is added to them, usually she will be unable to perform successfully both in and outside home. Such a perception is so widespread that today skills and specialization are merged with gender. The equation of man equal capable and woman equal incapable is considered so valid these days that when there is a woman performing a job ensures unimportance of skill and specialization in it. This leads to the opinion that the gender of the worker is a better indicator of its specialized nature (Pearson, 1992).

Ahmadi-Nia (2001) states that women's life in Iran and in the developing world is affected by the "views and ideologies of men in their environment. The man can be the father who supervises his daughter's level of education or the husband who determines his wife's continuing her studies or being active in society"(p, 37). Thus, Ala-Eddini (2005, p. 125) concludes that "women's dependence to family, their husbands' ideology and housework are the obstacles in the way of their effective participation in society and their promotion in various occupational and managerial positions".

Such issues are discussed in the Theory of Gender Differences, according to which there is a difference between the position and status of women and men. According to Jariah (2008) the unequal look at men's and women's roles stem from gender stereotypes that are formed in the cultural and traditional structure of a society and are closely related with the process of recognition in it. The members of any society recognize individuals based on their conventional and gender roles, according to which different behaviours are expected from men and women. According to this theory, for instance, society usually recognizes men as independent, brave, adventurous, able and controlling, but women are regarded as dependent, passive, sensitive, gentle and mild. As a result, this causes the traditional beliefs on the position of men and women, particularly in terms of their decision-making power in various social and political areas to survive, obstructing the development and process and progress of a country.

\subsection{Facilitating Factors}

Sociologists, experts and researchers in the area have suggested various methods to eliminate women's problems and facilitate the process of their active participations in different social and political areas. A group of these scholars believe that unless the culture and the mind frames in the society regarding women's participation shift, change through ratifying rules and new items will be superficial and temporary. Therefore, cultural solutions can help to eliminate the obstacles in the way of women's social and political participations. There is, however, another group that argues since changes in culture and mind frames in a society are longitudinal matters, ratifying rules and introducing new structures should facilitate women's social and political participations. Therefore, this group presents structural methods to eliminate barriers in the way of women's social and political participations. As it is evident in Iran, most of the factors preventing women from social and political 
participations can be categorized under cultural obstacles. It is for this reason that only strategies to transcend such barriers are focused on this paper.

As for the strategies to overcome Iranian women's social and political barriers, several solutions have been proposed. These include changing the traditional ideologies and the common views concerning women or establishing a system which benchmarks individuals' adequacy and appropriateness rather than their gender.

In relation to the strategies to overcome Iranian women's social and political barrier, Fakhraei (1996) states that individual and social renovation play major roles in rising women's political and social participations and development of a society. He further argues that social renovation necessitates change in different social organs and in social, economic and political systems in order for a society to grow and develop. If social changes are directed towards social renovation, they can influence people's activities and facilitate the process of achieving positive cultural values and norms. Individual renovation, on the other hand, necessitates change in individual ideology, personality and belief of every single member of a society. This type of renovation includes both external and internal aspects. The former relates to the environment, while the latter concerns with the views, values and emotions. Men should change their traditional view towards women and consider the unique and significant effects such change can bring about. Women, on the other hand, should believe in their capabilities, adequacies and potentialities and accept that their needs and demands should be taken into consideration as the other half of the society.

In fact, prioritizing social and individual renovation can eliminate many cultural barriers in the way of women's participation and help women to achieve appropriate positions in various social and political areas.

Education can also be mentioned as one of the fundamental ways to discard most of the barriers in women's participation. Through continuous education, the unrealistic perception regarding a certain paradox between women's family roles on one hand, while their social, political and managerial roles, on the other, are eliminated and their capabilities and adequacies emerge. Moreover, through education, individual's viewpoints, man or woman, concerning social participation are improved and an opportunity is gradually created to share women in decision-making and managerial affairs. In short, political and social awareness can be assumed as the root of growth in human societies, which is possible through education and training, which can consequently lead to a rise in women's social and political participations. As a matter of fact, raising the awareness of women, their literacy and educational level paves the way for a better social status for them and dilutes the patriarchy atmosphere prevalent in the families. In other words, a growth in the number of educated women will create a chance for the equality between the rights of men and women.

The role of multimedia should not be ignored in eliminating the barriers against women's participation. According to the results of an international research, the mass media, television in particular, have played a weak role in illustrating women's capabilities in social and political areas. The findings of this research further indicate that the multimedia, focusing on the traditional gender stereotypes, emphasize women's appropriate presence in home and among family members, and they either fail to portray or seldom show women's social activities and their high capabilities in various fields of politics, management and economy (Wirth, 2001).

Therefore, the mass media policy makers are responsible to wisely plan on and take measures in increasing the social awareness regarding the importance of women's social and political participations. In addition, educational programmes should be broadcast in relation to the self-consciousness of this particular half of the human society. The women, who confine themselves to the borderlines of home and family, are often insensitive to the events outside home, and this leads to the misunderstanding that they are unaware of various individual and social relationships. As the most crucial means to assist in women's socialization of politics and culture, the mass media should therefore produce and air various programmes which aim at increasing individuals' awareness in general and women's consciousness in particular.

An individual's inaccurate interpretation and understanding of Islam is another cultural factor abstracting women's participations. Although religious leaders and actual executives and scholars of religious studies argue for the equality and not similarity between men and women, there are still people who are unaware of the importance of women's presence in society and regard their status in an Islamic community with prejudice, seeking to transfer their dogmatic and prejudiced opinions to others. It is the duty of the thinkers and reformers of the society to shoulder the responsibility of making such individuals aware and clear about the wrong inferences and interpretations of religion and ideology, particularly in the present situation in which the society faces a shortage of skilled and specialized human resources.

Appointing conscientious managers in high-level decision-making positions can also solve many problems confronted by women. In fact, in high managerial levels, individuals who are well-aware of the cultural issues 
faced by the society, have management specializations and are not gender-based should be appointed so that they can create opportunities for women's co-operation in the social and political areas.

Meanwhile, the national and international gatherings and conferences, in which scholars and experts in the area of woman studies participate, can also be regarded as another cultural solution, and in which the ways to eliminate social and political obstacles are discussed. In addition, planning to utilize the experiences gained by other successful countries (where women are able to have an optimal share in different economical, social, political and cultural dimensions) can also be regarded as another way to increase women's participation.

It should, however, be mentioned that culture is a set of regular and unwritten rules for a better life and it is based on principles. Unless the other half of the society has not found the rights for social, political and economic activities, they can no longer trust in a culture which has granted the political and social rights to only one half of the community for centuries and which has confined the other half to housework. Thus, it is imperative to use all the available resources to change any cultural structure that seeks to outcast women from social and political fields even though it is to take decades.

Overall, however, it should be acknowledged that in order to make changes in the wrong views towards women and tackle the barriers obstructing their social and political participations, there should first be a transformation in women's own views. In other words, they should be conscious of their capabilities and potentialities and with self-confidence and by relying on themselves, they should take firm steps in their self-actualization. They should be empowered with knowledge and equipped with information so that they can prove that they deserve to co-operate in all managerial positions. More importantly, they should escape passivism and indifference and revolutionize themselves in order to reduce the distance between the status qua and their desired condition.

\subsection{Conclusion}

The condition of Iranian women's political participations in three different historical periods has been reviewed in this paper. In the first period, women's share in politics during the Qajar Dynasty was discussed. It was maintained that before constitutionalism, Iranian women lived in a traditional situation and there was no place for women in society. In this time, small groups of educated women (many of whom belonged to the upper caste of society) carried out actions to gain rights. However, these activities were inadequate, and due to their lack of knowledge, most women in that period were still not aware of their inalienable rights and suffered their traditional life.

Subsequently, the quality of women's political participations in the first and second Pahlavi was reviewed. Although in periods of the Pahlavi's despotism and pressure on religion and clergy existed, women's condition was improved. This process was continued until the Mohammad Reza Shah's period, in which a small population of women occupied high positions and took some responsibilities, although these women could not be representatives of the broad mass of Iranian women due to their dependence on the Court.

The women's political contributions in the Islamic Revolution and their roles in the process of this Revolution and the period following it have also been discussed. In addition, the facilitating and obstructing factors in the women's political participations in Iran were also taken into consideration. It was concluded that cultural barriers (e.g. gender bias and stereotypes that stemmed from the cultural and traditional structures of the Iranian society, were among the most crucial obstacles in the way of women's social and political participations. Hence, raising the self-awareness and scientific growth of women with the help of education, mass media, effective and scientific conferences on the condition of women's participations, change in the traditional structure, breaking the glass-ceilings, as well as elimination of gender stereotypes and change in the misinterpretation of Islamic principles regarding women's participation in society were suggested as crucial ways in which women's political participation could be improved.

Finally, it is important to point out that there is undoubtedly no society that can develop when half of the members of its population are regarded as nothing more than the second best citizens and their needs and demands to excel and develop are ignored. In other words, sustainable and rapid development occurs in a country where women and men, regardless of their genders, abreast of each other take steps in its grow.

\section{References}

Afarai, Z. (1998). Iranian Women's Forum in Constitutional Revolution (J. Usefiyan, Trans.). Tehran: Banoo

Ahmadi-Nia, S. (2001). Effective factors on women's participation in politics. Tehran: Sociology Forum.

Ala-Eddini, P. (2005). The condition of women's contribution and occupation in Iran. Research in Social Welfare Quarterly 12. 
Beck, L., \& Nashat, G. (2004). Women in Iran: From 1800 to the Islamic Republic. IL: University of Illinois.

Chaido, A. (2006). Changing Role of Women in Iran. University of Kansas, Kansas.

Davani, F. (2005). Women in their challenge with tradition: A research concerning women's social rights in Iran. Tehran: Nakhostin.

Delrish, B. (1996). Women in Qajar period. Tehran: Islamic Development Organization.

Enayat, H. (2001). Political Participation of Women in Iran: A Sociological Study. Panjab UniveRsity, Chandigarh.

Esfandiari, H. (1977). Reconstructed Lives: Women and Iran's Islamic Revolution. Washington D.C: John Hopkins University Press.

Fakhraei, S. (1996). Woman and the cultural development. Paper presented at the Fourth Congress of the Image of Women in Society.

Haas, W. S. (1946). Iran. . New York: Columbia University Press.

Huntington, S. (1965). Political Development and Political Decay. World Politics, 17(39), 389-430.

IPU. (2010). Women in national parliaments. Retrieved 28 February 2010, from http://www.ipu.org/wmn-e/classif.htm

Jaquette, J. S. (1997). Women in power: from Tokenism to critical mass Foreign Policy, 33.

Jariah, M. (2008). Gender in every life. Serdang: University Putra Malaysia Press.

Javaheri, F., \& Ghazati, s. (2007). Obstacles of women's occupation. Farhang va pazuhez, 12(3), 65-75.

Kar, M. (1977). Political rights of Iranian women. Tehran: Roshangeran.

Keddie, N. R., \& Richard, Y. (1981). Roots of revolution: an interpretive history of modern Iran. New Haven: Yale University Press.

Khalili, M. (2007). Pathology of women participation in contemporary Iran. Women study, 5(2).

khodadad, M. (2008). The Role of Women in the Constitutional Revolution. Tehran: Farhang-e- Eleya.

Khomeini, R.-O.-A. (1998). Sahifeyeh Noor. Tehran: Institute of Imam Khomeini's Publications.

Khomeini, R.-O.-A. (1999). Sahifeyeh Noor,. In (Vol. 5). Tehran: Institute of Imam Khomeini's Publications.

Khomeini, R.-O.-A. (2005). Sahifeyeh Noor. Tehran: Institute of Imam Khomeini's Publications.

Maknun, S. (2000). Feminism in Iran. Tehran: The Office of Human Science Research Center.

Mohammadi, Z. (2009). Iranian women and political activity. Retrieved Feb. 12, 2009, from http://www.women.org.ir/pages/content.php?id=2378

Molaverdi, S. (2005). Women in power and decision-making. Culture and Research Quarterly, 10.

Moore, G. E. (1988). Principia ethica. New York: Prometheus Books.

Mosaffa, N. (2000). Women's Empowerment in Iran the Practice of Political Development. Paper presented at the Muslim societies in the changing world: The dynamics of social transformation in the Middle East and central Asia.

Naji-Raad, M. A. ( 2003). Barriers of Women's Political and Economic Participation in Iran after the Revolution. Tehran: Kavir.

Pearson, R. (1992). Gender Issues in Industrialization in Hewitto T., johonson H. \& D. wield (Eds). Industrialization and Development. Oxford: Open University press.

Sansarian, E. (2005). The movement of women's rights in Iran. Tehran: Akhtaran.

Shaditalab, J. (2002). Development and challenges of Iranian women. Tehran: Ghatreh.

Shamim, A.-A. (2008). Iran during the Qajar monarchy: the thirteenth century and the first half of the fourteenth century $A H$. Tehran: Zar Yab.

Shojaei, Z. (2005). The status of women of the Islamic Republic of Iran: ten years after Beijing. Paper presented at the Beyond Beijing: Toward gender equality in politics(The 49th Session of the Commission on the Status of Women). 
Sook Kim, J. (2006). Women's political participation and strategies for gender equality. Paper presented at the 6th Asia Pacific Congress of Women in Politics.

Statistics Center of Iran. (2009). The Annual Statistics of Iran. Tehran: Statistics Center of Iran.

Topuzoglu. (2004). Middle Eastern Women's Participation in Politics. American University, Washington DC.

Topuzoglu, V. (2004). Middle Eastern Women's Participation in Politics. American University, Washington DC.

Wirth, L. (2001). Breaking through the glass ceiling: women in management. Geneva: International Labor Office

Woman Studies and Research Center of Tehran University. (2002). Introduction of Center. Retrieved Feb 12, 2009, from http://www.cwsut.com/news.php?item.8.1

\section{Notes}

Note 1.Qajar Dynasty was a family who ruled on Iran from 1794 to 1925.

Note 2.Pahlavi Dynasty is created by the Iranian parliament on 12 December 1925 and appointed Reza Shah Pahlavi as a first King of Pahlavi Dynasty. This Dynasty ruled Iran from 1925-1979.

Note 3.He was a famous clergyman in the Iranian and Iraq History (1814-1896). He is known for his fatwa against the use of tobaccos which was later known as the Tobacco Protest in the Qajar period.

Note 4.He was the Iranian King from 1848 to 1896 . He had ruled for almost 50 years.

Table 1. Female and male members of the Iranian Parliament during its 8 terms (Statistics Center of Iran, 2009)

\begin{tabular}{|c|l|l|c|c|c|c|}
\hline \multirow{2}{*}{ Period } & \multirow{2}{*}{\begin{tabular}{l}
\multirow{2}{*}{$\begin{array}{l}\text { Yotal } \\
\text { Seats }\end{array}$} \\
\cline { 4 - 7 }
\end{tabular}} & & \multicolumn{2}{|c|}{ Female } & \multicolumn{2}{c|}{ Male } \\
\cline { 4 - 7 } & & NO. & $\%$ & NO. & $\%$ \\
\hline First & 1980 & 270 & 4 & 1.4 & 266 & 98.6 \\
\hline Second & 1984 & 270 & 4 & 1.4 & 266 & 98.6 \\
\hline Third & 1988 & 270 & 4 & 1.4 & 266 & 98.6 \\
\hline Forth & 1992 & 270 & 9 & 3.3 & 261 & 96.7 \\
\hline Fifth & 1996 & 270 & 14 & 5.2 & 256 & 94.8 \\
\hline Sixth & 2000 & 270 & 12 & 4.4 & 258 & 95.6 \\
\hline Seventh & 2004 & 290 & 14 & 4.8 & 276 & 95.2 \\
\hline Eighth & 2008 & 290 & 8 & 2.7 & 282 & 97.3 \\
\hline
\end{tabular}

The data presented in the table above show that the rate of the Iranian females' participations during the last 8 Parliaments did not exceed 5.2 percent. 